\title{
Videopelikokemuksen kansanomaisuus
}

\author{
Lectio praecursoria Turun yliopistossa 14.4.2018
}

\author{
Jukka Vahlo
}

Videopeli on tuote, joka on ostettavissa kaupan hyllyltä tai ladattavissa maksua vastaan verkkokaupasta omalle pelikoneelle. Mitä tekemistä videopeleillä on kansankulttuureja ja perinnemuotoja tutkivan folkloristisen tutkimuksen kanssa? Tämän kysymyksen perusteellinen pohdiskelu edellyttää, että perehdymme ensiksi kysymykseen pelin ontologiasta - eli kysymme: miten peli on olemassa itsenäisenä ilmiönä?

Ilmiöiden tutkimus kuuluu fenomenologian kenttään: fenomenologian tehtävänä on tut-

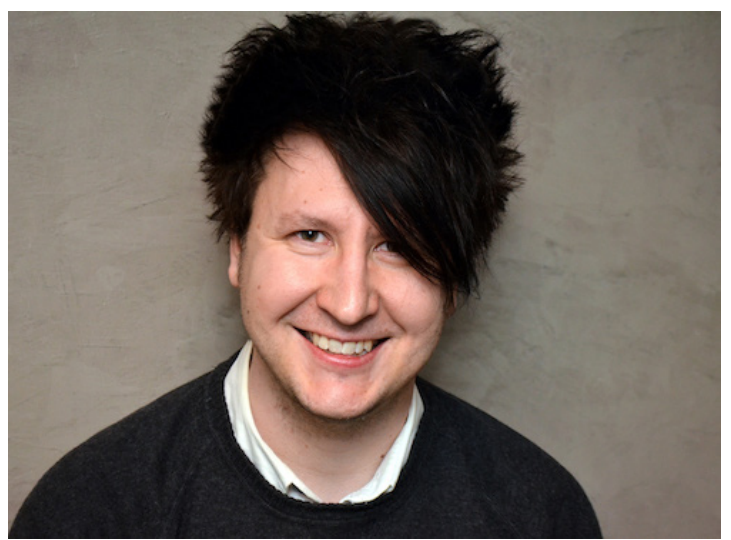

Jukka Vahlo kia, miten todellisuus ilmenee ihmiselle hänen omassa kokemusmaailmassaan (Thompson 2007). Nimitän fenomenologisesti orientoitunutta folkloristista tutkimusotettani ensimmäisen persoonan folkloristiikaksi juuri siitä syystä, että tutkimukseni huomio kiinnittyy pelaajien tapoihin kokea, reflektoida ja muistella videopelaamistaan. Analysoin tutkimuksessani, mitkä ominaisuudet ovat läsnä jokaisessa videopelin kokemuksessa, ja mitkä piirteet vastaavasti vaihtelevat pelaajien ja pelikertojen välillä. Tämä rajaus on olennainen folkloristiikalle, joka tieteenalana tutkii hitaasti muuntuvia traditioita ja niiden muuntelua eli variaatiota erilaissa kulttuurisissa käyttöyhteyksissä.

Fenomenologiseen tutkimukseen painottuva ensimmäisen persoonan näkökulma soveltuu hyvin folkloristille, sillä kuten Robert A. Georges totesi jo 1960-luvulla (Georges, 1969), folkloristiikka on erityisen kiinnostunut kokijan näkökulman ymmärtämisestä sekä analysoimaan sitä, miten yksilöt ja yhteisöt muovaavat kulttuurin ja yhteiskunnan vallitsevia rakenteita. Tarkastelen ensimmäisen persoonan näkökulmasta, miten videopeli on olemassa itsenäisenä ilmiönä pelaajan omassa kokemusmaailmassa.

Videopeli on kaupallinen esine, ja sama huomio pätee useimpiin lautapeleihin ja korttipeleihin. Mutta pelin määritelmä on vaillinainen, jos yritämme kuvata peliä ainoastaan esineenä. Yhtä lailla, tai kenties vieläkin tärkeämmin, peli on sen pelaamisen tapa. Videopeli ei ole ainoastaan koodi, sarja sääntöjä, tai pelin ennalta määritelty tavoite - siis mitä voimme 
sanoa löytyvän pelikotelon sisältä. Peli on myös se, miten peliä pelataan eli mitä peli tarkoittaa pelaajan ja pelin välisessä vuorovaikutuksessa (Aarseth 2014).

Toisin kuin kirjaa lukiessamme tai elokuvia katsellessamme, peleissä me vaikutamme aktiivisesti ja suoraan siihen, minkälainen dramaattinen rakenne pelille muodostuu. Tätä rakennetta ei voida palauttaa pelkästään pelituotteen ominaisuuksiin eikä liioin pelaajan persoonaan. Pelin dramaattinen rakenne on pelaajan ja pelin vuorovaikutuksessa muovautuva ainutkertainen kokonaisuus, jossa kaupallisuus ja institutionaalisuus kohtaavat pelaajan toimijuuden, tunteet ja kulttuurisen kontekstin. Etnomusikologi Kiri Miller $(2008 ; 2012)$ on esittänyt, että pelaaminen on luonteeltaan niin sanottu folkloristinen teksti (Titon 1995), joka esiintyy muuntelevina, mutta toisiaan muistuttavina versioina.

Folkloren tärkeä tehtävä yhteiskunnassa on kommentoida, kritisoida ja asettaa vakiintunut institutionaalinen rakenne naurunalaiseksi. Näin toimii myös pelaaja: pelin säännöt ovat rakenne, jota vastaan pelaaja asettuu. Hänen tulee toimia sääntöjen asettamissa rajoissa, mutta pelaaja on vapaa tekemään säännöistä omat tulkintansa sekä kritisoimaan, muuntelemaan ja jopa rikkomaan niitä.

Pelaaja on siis toisaalta vapaasti kokeileva ja toisaalta pelin sääntöihin ja tavoitteisiin mukautuva subjekti. Tämä kokeilevuuden ja mukautuvuuden yhteys läpäisee kaikkea pelaamista, ja kumpaakin toimintoa voidaan pitää välttämättömänä pelaamiselle itsenäisenä ilmiönä. Sillä jos henkilö kiinnittyy ainoastaan vapaaseen kokeilevuuteen, olemme tekemisissä leikin, emme pelaamisen kanssa. Jos toisaalta henkilö yrittää ainoastaan mukautua teknologian asettamiin vaatimuksiin, hän ei pelaa vaan käyttää peliä.

Ilmiöitä tutkivan fenomenologisen tutkimuksen näkökulmasta voidaan sanoa, että folkloristiikka toimii yhteiskunnassa pelaamista vastaavalla tavalla: uutta folklorea luovan tulee sekä kokeilla ja haastaa olemassa oleva institutionaalinen kulttuuri että mukautua sen rajoihin. Meemit ovat hyvä esimerkki tästä folkloristisesta modifikaation käytänteestä. Uusi folklore luodaan kokeilevuuden ja mukautuvuuden vuorovaikutuksessa, ja tämä tanssi vie myös jokaista pelikokemusta eteenpäin.

\section{Pelikokemuksen kertomuksellinen rakenne}

Pelaajan ja pelin hetkellinen vuorovaikutustilanne eli pelaaminen (eng. gameplay), tuottaa kokemuksen, jolla on tyypillisen, prototyyppisen kertomuksen rakenne. Kuten kertomukset, myös pelikokemukset muodostuvat toisiinsa ajallisesti ja kausaalisesti yhteydessä olevista tapahtumista sekä haasteista ja konflikteista, joita päähenkilö eli pelaaja kohtaa (ks. Abbott 2002).

Kuitenkaan peli ei itsessään ole kertomus, sillä pelistä puuttuu kerronnan tilanne. Pelaajan positio ei myöskään ole kertojan positio, vaan kokijan ja osallistujan positio. Silti pelikokemus poikkeaa muista arkisista kokemuksistamme nimenomaan siinä, että pelikokemuksen luonne on aina dramaattinen (Goffman 1986 [1974]; Abrahams 2005). Tämä käy ilmi jo siitä viehätyksestä, mikä liittyy esimerkiksi urheilutapahtumien seuraamiseen tai YouTuben suosituimman käyttäjälähtöisen sisällön eli let's play -videoiden katseluun: pelikokemuksen rakenne sisältää aina draaman kaaren. 
Pelikokemus on aina myös lähtökohtaisesti tunteisiin vetoava tapahtuma. Jotta voimme pelata, meidän tulee omaksua pelitilanteessa ilmenevä pelaajan identiteetti. Olennaisilta osin tämä identiteetti hajoaa pelin päättyessä. Fenomenologialle läheisen enaktiivisen kognitiotieteen mukaan me olemme aina affektiivisessa tilassa, koska jokainen kokemuksemme on yhteydessä omaan autonomiaamme ja identiteettiimme (Colombetti 2014). Vastaavalla tavalla pelikokemuksen aikana pelitilanteet ovat yhteydessä identiteettiimme pelaajana. Niin kauan kuin olemme motivoituneita pelaamaan, pelikokemukset ovat siis meille emotionaalisia, sillä niihin rakentuu aina uhka tilannekohtaisen pelaajan identiteettimme kannalta. Esimerkiksi kauhupelien pelaaja pelkää aivan oikeasti, vaikka hän tietääkin, etteivät pelitilanteet ole totta ja siten uhka hänelle itselleen. Ne ovat silti uhka hänellä pelaajana, ja koska pelaaja välittää pelaajan identiteetistään, pelitilanteet ovat hänelle aidosti pelottavia.

Peli esineenä toimii emotionaalisesti relevantteja kertomuksia tuottavana järjestelmänä, kertomuskoneena. Vaikuttavimmillaan nämä kertomukselliset rakenteet liikuttavat niin yksilöitä kuin yhteisöjäkin. "Never forget", kuten jääkiekon vuoden '95 maailmanmestaruutta muistelevat tapaavat sanoa. Haluammekin usein keskustella tunteisiin vedonneista pelikokemuksistamme myös muiden sellaisten henkilöiden kanssa, jotka ovat olleet samassa pelimaailmassa kuin mekin, ja siten kokeneet jotakin samankaltaista. Tässä mielessä pelikokemukset ovat ensimmäisen persoonan näkökulmasta kuin matkoja vieraisiin paikkoihin, joista vain toisilla samassa paikassa käyneillä on omiamme vastaavia kokemuksia.

Pelikokemuksen dramaattinen rakenne erottaa pelikokemukset sekä leikkikokemuksesta että teknologian käyttökokemuksesta. Vaikka arkisessa elämässä voimme kokea vastaavaa merkityksellisyyttä, jossa asiat ikään kuin tapahtuvat ennalta määrätyssä järjestyksessä ja ovat osa suurempaa kokonaisuutta tai tarkoitusta, tämä arkielämässä poikkeuksellinen kokemusmuoto on sisäänrakennettu jokaiseen pelikokemukseen.

\section{Videopelikokemukset ja perinteiset pihapelit}

Pelaajan positioon liittyy lukuisia erityispiirteitä, jotka erottavat pelikokemukset muista kokemuksistamme. Voimme ottaa pelikokemukset tosissaan - ja näin tulisikin tehdä - mutta vakavia ne eivät ole. Suuttumus pelissä tulisi jäädä pelikokemuksen aikaiseksi, eikä pelaamisen aikana tapahtuvan selkäänpuukotuksen tulisi pilata ihmissuhteita. Ei ainakaan pysyvästi. Olemme pelikokemuksen päähenkilöitä, mutta ensisijaisesti olemme sitä pelaajina emmekä yksityishenkilöinä. Koemme pelien tapahtumat pelaajan naamion eli pelaajapersoonamme läpi. Tämä pelaamisen välttämätön rakenne tarkoittaa, että pelitilanne on aina myös performatiivinen: ilmaisemme itseämme pelin esityksellisessä rakenteessa, joka on osittain pelin sääntöjen määrittelemä, ja kuitenkin vapaa omille tulkinnoillemme.

Pelaajien muistelut liittyvät myös pelaajan maskiin. Havaitsin pelaajahaastatteluissani, että muistelemme pelikokemuksiamme usein nimenomaan pelaajapersooniemme näkökulmasta (vrt. Stahl 2008 [1989]). Kertomuksellisen ja performatiivisen rakenteensa ansiosta videopelien pelaaminen ilmiönä säilyttää saman kansanomaisen luonteensa, jonka folkloristit tunnistivat pihapeleille jo 1800-luvun lopulla. Se seikka, että videopeli on kaupallinen tuote, ei muuta tätä perusasetelmaa.

Kenties tärkein yhteys videopelien ja perinteisten pihapelien välillä näyttäytyy tutkimalla pelaajan ja pelin vuorovaikutusmuotoja. Pelinkehityksessä näitä suunnittelutyön 
perusyksikköjä kutsutaan pelimekaniikoiksi, ja niillä kuvataan niitä menetelmiä, joilla pelaajan toiminta kuten peliohjaimen napin painallus muutetaan vastaamaan pelissä ennalta määriteltyä pelinsisäistä toimintoa (Sicart 2009).

Esimerkiksi painamalla Playstation-peliohjaimen painiketta X, pelihahmoni pelissä Persona 5 (Atlus 2017) hyppää. Hyppääminen on siis yksi tämän pelin pelimekaniikoista. Kun otamme tarkasteluun myös aikaulottuvuuden, siis miten pelaajan toiminnallisuus yhdistyy pelimekaniikkojen sarjoihin pelaamisen aikana, puhumme pelidynamiikoista (Vahlo et al. 2017). Tällaisia voivat olla esimerkiksi pelaajan kokemus autolla ajamisesta, strategisesta sodankäynnistä tai ystävystymisestä muiden pelihahmojen kanssa.

Pelidynamiikat ovat olennaisia videopelikulttuureille ja peliliiketoiminnalle. Tämä seikka paljastuu jo siinä, että videopeligenret nimetään lähes yksinomaan pelien keskeisen pelidynamiikkatyyppien mukaan. Puhumme toimintapeleistä, roolipeleistä, strategiapeleistä, seikkailupeleistä, tasohyppelyistä ja pulmapeleistä. Kaupallisten videopeligenrenimikkeiden folkloristinen tarkastelu kuitenkin paljastaa, että vallitsevat genre-nimet eivät ole kaupallisen videopeliliiketoiminnan tuotosta vaan jatkumoa sille, miten perinteiset pihaleikit ja sosiaaliset pelit eroteltiin toisistaan. Ammuskelu- ja pussailuleikkejä ja -pihapelejä on aina pidetty toisistaan eroavina. Videopelikulttuurien genre-nimikkeissä huomio kiinnittyy siihen, minkälaiseen toimintaan pelaaja pelatessaan keskittyy. Videopelien pelaaminen ei ole kulttuurisena ilmiönä eroteltavissa perinteisistä pihapelien pelaamisesta, ja tästäkin syystä folkloristisen tutkimuksen tulisi olla kiinnostunut myös kaupallisista peleistä.

\section{Pelidynamiikat ja pelaajatypologiat}

Pelidynamiikat, eli pelaaja-peli-vuorovaikutuksen toistuvat muodot ovat sekä perinteisten pihapelien että videopelien välttämättömiä ominaisuuksia. Mutta mitä nämä videopelien dynamiikat ovat, ja voidaanko erilaisia pelaajatyyppejä tunnistaa sen mukaan, minkälaisia dynamiikkoja he pitävät mieluisina ja toisaalta epämieluisina?

Tutkin tätä kysymystä toteuttamalla ensin laadullisen sisällönanalyysin 700 videopelin peliarvostelu-artikkelille. Analyysissa havaitsin, että pelidynamiikkojen kuvaaminen on olennainen osa pelijournalismia. Jokaisessa analysoimassani artikkelissa oli vähintään yksi kuvaus pelidynamiikasta eli pelaajan keskeisestä toiminnasta pelin etenemisen kannalta. Kuvauksia kertyi yhteensä 2900, ja luokittelin nämä korkeamman abstraktiotason ryhmissä yhteensä 33 pelidynamiikka-kategoriaan. Tällaisia kategorioita ovat esimerkiksi harvinaisten aarteiden etsiminen, kaupunkien rakentaminen, tappaminen, lemmikkieläinten hoivaaminen ja palikoiden yhdisteleminen.

Liitimme nämä 33 pelidynamiikkakuvausta Suomesta ja Tanskasta kerättyihin, väestöä edustaviin kyselytutkimuksiin, joihin vastasi yhteensä lähes 2600 henkilöä. Kysyimme kaikenikäisiltä vastaajilta, miten mieluisina he pitivät videopelikulttuurien pelidynamiikkoja. Eksploratiivinen faktorianalyysi osoitti, että pelaamismieltymykset koostuvat viidestä ulottuvuudesta, jotka nimesimme aggressioksi, johtamiseksi, tutkiskeluksi, koordinaatioksi ja huolenpidoksi.

Havaitsimme, että pelaajatyyppejä eli pelaajapersoonia on mahdollista tunnistaa näiden viiden ulottuvuuden mukaan. Yhteensä noin kahdentuhannen vastaajan aineistosta nousi 
tilastotieteellisin klusterianalyysimenetelmin seitsemän pelaajapersoonaa kuten Palkkasoturi, joka pitää aggressiivisesta ja tutkiskelevasta pelaamisesta, mutta ei voi sietää huolenpitoa. Tai Seikkailija, joka pitää tutkiskelevasta ja koordinaatiotaitoja vaativasta pelaamisesta, mutta ei ihmisryhmien johtamisesta tai joukkojen komentamisesta.

Pelaamismieltymysten mukaan tunnistetut pelaajapersoonat jatkavat folkloristisen tutkimuksen perinnettä tunnistaa ja analysoida erilaisia kertojatyyppejä (Siikala, 1990). Ne auttavat ymmärtämään pelaamiseen liitettyjä yksilötason merkityksiä ja pelaamista kulttuurisena ilmiönä. Havaitsin tutkimuksessani, että pelaajapersoonat eroavat toisistaan myös siinä, minkälaisia tunnekokemuksia he pitävät miellyttävinä, ja miten tärkeänä he pitävät peliharrastustaan. Toiset pelaajapersoonat myös muistelivat pelaajahaastatteluissani pelikokemuksiaan muita pelaajapersoonia monipuolisemmin ja yksityiskohtaisemmin.

Pelaajapersoonat ovat arvokkaita myös pelinkehitykselle, sillä niiden avulla peliyritykset voivat ottaa huomioon erilaiset pelaajasegmentit. Psykologisen tutkimuksen kannalta on lisäksi tärkeää kysyä, ovatko temperamenttityypit ja pelaajapersoonat yhteydessä toinen toisiinsa. Pelaajapersoonat auttavat meitä ymmärtämään myös sitä, miksi ylipäätään pelaamme videopelejä.

\section{Onko pelaaminen vain viihdettä ja ajantappoa?}

Julkisessa keskustelussa vallitsee kapea käsitys videopelien pelaamisen syistä. Pelaamista kuvataan tyypillisesti pelkkänä viihteenä tai ajantappona. Jälkimmäinen kuvaus liitetään nykyään voimakkaasti erityisesti mobiilipelien pelaamiseen.

Havaitsin kyselyaineiston faktorianalyyttisissä tutkimuksissani, että suomalaiset ja tanskalaiset pelaavat videopelejä viidestä syystä: toimiakseen itsenäisesti ja autonomisesti, saadakseen taidoilleen sopivia haasteita, viettääkseen aikaa muiden pelaajien kanssa, uppoutuakseen pelimaailmoihin eli immersion takia sekä pelaamisen hauskuuden vuoksi. Tämä viiden faktorin malli on yhteensopiva psykologisen itsemääräytymisteorian kanssa.

Mutta mitä oikeastaan tarkoittaa, että pelaaminen on hauskaa? Entä miten pelaaja uppoutuu pelimaailmoihin? Näiden kysymysten rakenneyhtälömallinnukseen perustuvan analysoinnin tuloksena esitän, että haasteiden takia pelaaminen ennustaa toivetta pelaamisen hauskuudesta, ja että kokemus vapaasta, autonomisesta itseilmaisusta ennustaa toivetta pelimaailmoihin uppoutumisesta. Havaitsin lisäksi, että haastavia ja hauskoja pelikokemuksia toivovat pelaajat kokivat palkitsevimman pelaamisen lähinnä viihdyttäväksi kun taas itseilmaisua ja immersiivisyyttä etsivät pelaajat kokivat parhaat pelikokemuksensa syvemmällä tavalla merkityksellisiksi ja mieleenpainuviksi.

Folkloristinen tutkimus on jäänyt vieraaksi niin sanotussa game studies -kentässä, joka tutkii pääasiassa kaupallisia videopelejä ja niiden kulttuurisia merkityksiä. Osoitan väitöstutkimuksessani, että folkloristiikalla on paljon annettavaa videopelitutkimukselle, ja että kaupallisten tuotteiden kokemisen tavat, niiden muisteleminen ja muistojen jakaminen erilaisissa verkostoissa sopivat hyvin nykyaikaisen folkloristiikan tutkimuskohteiksi. 
Vahlo, Jukka 2018. In Gameplay. The Invariant Structures and Varieties of the Video Game Gameplay Experience. Annales B451.Turun yliopisto: Turku. http://urn.fi/ URN:ISBN:978-951-29-7169-5

\section{Kirjallisuus}

Aarseth, Espen 2014: Ontology. - Wolf, Mark J. P. \& Bernard Perron (eds.), The Routledge Companion to Video Game Studies. New York \& London: Routledge. 484-492.

Abbott, Porter H. 2002: The Cambridge Introduction to Narrative. Cambridge: University of Cambridge Press.

Abrahams, Roger D. 2005: Everyday Life: A Poetics of Vernacular Practices. Philadelphia: University of Pennsylvania Press.

Colombetti, Giovanna 2014: The Feeling Body. Affective Science Meets the Enactive Mind. Cambridge, MA:The MIT Press.

Georges, Robert A. 1969: The Relevance of Models for Analyses of Traditional Play Activities. - Southern Folklore Quarterly 23: 1-23.

Goffman, Erving 1986: Frame Analysis. An Essay on the Organization of Experience. Boston: Northeastern University Press. [1974]

Miller, Kiri 2008: Grove Street Grimm: "Grand Theft Auto" and Digital Folklore. - Journal of American Folklore 121(481): 255-285.

Miller, Kiri 2012: Playing Along. Digital Games, YouTube, and Virtual Performance. Oxford: Oxford University Press.

Sicart, Miguel 2009: Defining Game Mechanics. Game Studies 8(2).

Siikala, Anna-Leena 1990: Interpreting oral narrative. Helsinki: Suomalainen tiedeakatemia.

Stahl, Sandra Dolby 2008: Literary Folkloristics and the Personal Narrative. Bloomington: Trickster Press. [1989]

Thompson, Evan 2007: Mind in Life. Biology, Phenomenology, and the Sciences of Mind. Cambridge: The Belknap Press of Harvard University Press.

Titon, Jeff Todd 1995: Text. - Journal of American Folklore 108(430): 433-448.

Vahlo, Jukka, Johanna Kaakinen, Suvi Holm \& Aki Koponen 2017: Digital Game Dynamics Preferences and Player Types. - Journal of Computer-Mediated Communication 22(2): 88-103. DOI: $10.1111 /$ jcc4.12181 